\title{
Chapter 6. POLICIES PROMOTING THE USE OF CATALAN IN ORAL COMMUNICATIONS AND TO IMPROVE ATTITUDES TOWARDS THE LANGUAGE
}

\author{
Emili Boix \\ University of Barcelona, Barcelona, Catalonia, Spain
}

\author{
Joan Melià \\ University of the Balearic Islands, Balearic Islands, Spain
}

\section{Brauli Montoya}

University of Alicante, Valencia Region, Spain

\section{Abstract}

The first section of this article introduces the problem of usage norms that are detrimental to Catalan in interpersonal relations between Castilian and Catalan speakers. It goes on to describe the main campaigns promoting the use of Catalan in these intergroup relations, from El català és cosa de tots (Catalonia, 1981) to Integra'm, Integra'l (Minorca, 2005-2006), including on the way other Catalan, Balearic and Valencian campaigns. To conclude, it points to, on the one hand, the limits of these campaigns within a liberal democratic framework and, on the other, the difficulties in assessing their effects on everyday competences, usages and attitudes.

\section{Contents}

Abstract 1

1. Introduction 2

2. The problem 3

3. The beginnings of official language policy (1981-1995) 8

3.1. The "la Norma" campaign (1981): "El català és cosa de tots" 8

3.2. From "Parlem valencià" (1984) to "Visquem en valencià" (1990): an ambitious programme?

3.3. The first campaign in the Balearic Islands: "No et mosseguis la llengua" and "Treu la llengua" (1991-1992) 18

\section{The changes in language policy in the second phase (from 1995)}

4.1. A second try in Catalonia: the "Tu ets mestre" and "Tu hi guanyes" campaigns (2003) 20

4.1.1. The "Tu ets mestre" campaign (2003) 21

4.1.2. The "En català, tu hi guanyes" campaign (June 2003)

4.2. The last tries

4.2.1. A third try: "La Queta: dóna corda al català" (2005) 23

4.2.2. A fourth try: "Encomana'm el català" (2008)

4.3. Campaigns in Valencia, 1995-2007: the Generalitat versus the universities and the municipal councils 
4.4. Campaigns in the Balearic Islands between 1999 and 2003

4.4.1. "Donem la nostra llengua al futur" and "El català, una llengua per a tothom" (2000-2003). 33

4.4.2. Two campaigns by the Island Councils: "Tenim una llengua per sentir" (2004) and "Integra'm. Integra'l" (2005-2006)38

\section{Conclusions 39 \\ 6. Bibliography 40}

\section{Introduction}

Ever since the establishment of Spain's “autonomous communities", each of these communities with a native tongue other than Castilian in a part or all of its territory has carried out specific recognition of its own linguistic diversity and has implemented a unique language policy model based, fundamentally, on two interrelated variables that have been referred to in previous chapters. These are, firstly, social and political mobilisation in defence of each autonomous community's own language and the nationalist, language and identity-related commitment of their respective governments. This political process also explains how it is that, in Spain, no language communities are recognised, except for the Castilian-speaking one (which enjoys this recognition implicitly) and that, consequently, speakers of the same language may enjoy different degrees of recognition of rights and linguistic security from one autonomous community to another. Thus it is, for example, that the Catalan-speaking community is subject, within the Spanish state alone, to five language policies and five different language rights systems: those of Catalonia, the Balearic Islands, Valencia, Aragon and Murcia (A. Bodoque 2007).

The above situation revealed by Bodoque shows how impossible it is to talk of one single Catalan language policy, without territorial restriction. The factors affecting the sociolinguistic situation in Catalan-speaking territories occur with different levels of intensity. Again according to Bodoque, the three main Catalan-speaking territories, which will be the subject of attention in this Chapter, can be broken down into two groups. On the one hand there is Catalonia, which has always had favourable governments and a language policy of "normalisation", according to the terminology employed by this author and, on the other, there are the Catalan-speaking areas of Valencia and the Balearic Islands, with governments who are unfavourable and with policies of "promotion". 
As is well-enough known, in Catalonia, social modernisation, cultural renaissance and nationalist mobilisation made it possible for the $20^{\text {th }}$ century to witness brief periods of political autonomy (during the Mancomunitat of 1914-1925 and the Second Republic of 1931-1939) and for the regulation of the language to achieve an important landmark with the acceptation of the reforms of Pompeu Fabra. In contrast, neither Valencia nor the Balearic Islands achieved their own political power, although Pompeu Fabra's reforms were broadly accepted across the spectrum of those using Catalan as a form of educated expression. Franco's long dictatorship (1939-1975), with its associated political and cultural oppression, consolidated the trend towards diglossia in a significant proportion of the population and, by means of both generalised schooling (firstly) and, later, the mass media, completed the process of making native Catalans bilingual, so that Castilian put down strong social roots (Vila-Pujol 2007, Blas-Arroyo 2007, Gimeno-Menéndez and Gómez-Molina 2007). It is to be supposed that, due to the pressure exerted by the political powers that be to this end, this period also saw consolidation of the habit of switching to the language of the Castilian-speakers they were conversing with.

The revival of Catalan since 1975 has led to an uneven degree of bilingualisation of the population. All native Catalan speakers can also speak Castilian. However, the reverse is not true: not all Castilian speakers (the great majority of whom come from nonCatalan families) can speak Catalan, even though the new Catalan statute of 2006 establishes this as a duty for the entire population. Such an obligation is not, however, included in the new statutes of either Valencia $(2006)^{1}$ or the Balearic Islands $(2007)^{2}$.

\section{The problem}

For important segments of the Catalan community, the Catalan language remained a language of prestige during Franco's dictatorship. Nevertheless, some observation based on impressions and important ethnographic studies (Calsamiglia and Tuson 1980; Woolard 1983, 1985) have indicated how the so-called "accommodation norm" has been the predominant unwritten rule in the majority of social environments. This norm, described by Howard Giles in his psycho-sociological research (Giles \& Johnson 1981, Street \& Giles 1982), indicates that, in inter-ethnic relations, Catalans have to change

\footnotetext{
1 http://www.cortsvalencianes.es/descarga/destacados/ESTATUT.pdf

2 http://www.reformaestatut.org/refestatfront/index.ct.jsp\#
} 
language when conversing with Castilian speakers. They speak to fellow-Catalans in Catalan in the presence of Castilian speakers, but change to Castilian when addressing the latter or the group as a whole. Likewise, interactions with foreigners involve similar adaptive choices, with subtle hints (such as the physical appearance and accent of the interlocutor, where the interaction takes place, etc.) causing an apparently automatic and unconscious convergence (Genesee 1982) into Castilian by Catalan speakers -the result, in reality, of long periods in the past of social and political subordination.

Generally speaking, for Catalan speakers to decide to converse in the language with their interlocutors, it is not enough that the latter understand it, nor that they have a minimum command of the spoken language: it has to be their first language or they must speak it relatively fluently. Exceptions to this rule are provided by Catalan speakers who make a conscious, militant choice of language: in such instances, cases of "passive bilingualism" may arise. This type of behaviour has been promoted by the media in the hands of the Generalitat de Catalunya, and has doubtless given it legitimacy and caused its spread. Nevertheless, it is still only carried out by a minority. Around half the population of Catalonia and the Balearic Islands is "Castilian", in the sense that its everyday language is Castilian and the majority of its family roots lie outside Catalan-speaking territory. By way of contrast, in Valencia, two thirds of inhabitants use Castilian as their habitual language of communication, but the majority of them are local. We are distinguishing this Castilian-speaking population from more recent immigrants from Latin America, Eastern Europe, North and Sub-Saharan Africa, whom we shall not be dealing with. In fact, the former are not now usually called "immigrants". In the $21^{\text {st }}$ century, these ethno-linguistic labels (Catalan and Castilian) are probably no longer valid, but have not yet completely disappeared. Compulsory education (above all in experiences of mass immersion) and the "Catalanisation" of local and autonomous community authorities and of some media have allowed for a significant dissemination of knowledge of Catalan, which in the Catalonia of the nineties approached the level of complete bilingualisation of the population, at least on a passive basis. New immigration has led to an increase in the number of residents speaking Castilian but not Catalan, since integration tends to be carried out in the former language. Despite this, Catalan has, on a secondary basis and in certain sectors, a relative importance (in infants attending school in certain areas of Catalonia and the Balearic Islands, and even Valencia). Whatever the case, "Castilians" rarely learn 
Catalan in the same proportion that "Catalans" learn Castilian. Normally, the Castilian/Catalan bilingualisation of non-Catalan-speakers approaches the level of passive understanding but less frequently that of oral fluency. This is especially true of the metropolitan areas of Barcelona, Tarragona, Ibiza, Palma and other tourist areas of the Balearic Islands, which are home to the majority of immigrants, and the greater part of Valencia.

The current accommodation norm of turning to Castilian in interactions between "Catalans" and "Castilians" is one of the main obstacles to speakers of Castilian or other languages learning Catalan. Thus it is that conversation text books for Catalan have a saying, Si us plau parli'm (or parla'm) en català (Please speak to me in Catalan), which would seem incredible in those of dominant languages such as Castilian, English or French. Calsamiglia and Tuson (1984) concluded that this linguistic label "facilitated communication but made it more difficult for Castilian speakers to become actively bilingual, because they have no need to speak Catalan”. Woolard (1983:165) added that this linguistic label fulfilled the role of keeping up the linguistic barriers between the two groups. Thus it is that "Catalans" use Catalan in situations classified as ethnically Catalan. In such conditions, it is extremely difficult for newcomers (Castilian speakers or otherwise) to feel any need to learn Catalan or, in cases where they have done so, for them to become properly fluent in the language, because it is unusual for Catalans to continue to address them in Catalan if they realise they are not from a Catalan background.

We can see many examples of the application of usage norms in a range of communication situations. Those in which it is stipulated or understood that one should address an audience in Catalan show us how the rule can be broken when there is involvement from the public in Castilian. Then, given that there will be personalised attention, it appears legitimate for the teacher or speaker to change language. However, this "breaking" of the rule occurs more frequently amongst Catalan-speaking members of the audience, who have greater freedom to not continue speaking Catalan with their Castilian-speaking colleagues, even after unsuccessful, if at times explicit, attempts by the latter to express themselves in Catalan.

At the beginning of the eighties, Calsamiglia and Tuson (1984:119), on the basis of observations made in 1980, noted that a "bilingual norm" appeared to be emerging, which competed with the "accommodation norm" and whereby each speaker would 
keep to their own language, whatever the linguistic or ethnic identity of their interlocutor. Clearly, there are far more complex "mixed" strategies. A Catalan speaker may consciously mix the two languages when addressing a Castilian speaker, or slow down their speech, or make use of a vocabulary that is closer to Castilian. This is a case of asymmetrical psychological divergence, however, because Castilian speakers who cannot speak Catalan cannot really diverge. It is no wonder that this "passive bilingualism" faces significant psychosocial and political problems:

(a) Firstly, many Catalans addressing Castilians find it strange and unusual to speak to them in Catalan, because they have to overcome the fear of being mistakenly viewed as threatening, provocative or rude, with a lack of politesse, by carrying out a face-threatening act. To avoid this confrontational interpretation, "Catalans" need to offer signs of psychological convergence through prosody, intonation, gestures and, evidently, the same referential content ${ }^{3}$.

(b) The ethnic divisions between Castilians and Catalans in Catalonia are, broadly speaking, parallel to those of social status: it is more probable that Catalans are on the higher steps of the social ladder, although there is a greater presence of those habitually speaking Castilian at the very top. Catalan has connotations of a "select" language. By way of contrast, in the Balearic Islands, Catalan is associated with the native inhabitants and older individuals, and is less linked with the top and bottom social levels, reserved for Castilian. As so well described by Woolard, the hypothetical internal conflict between "Catalans" and "Castilians" is interlinked with the conflict between the Catalan and Spanish governments, in which the latter tends to defend Castilian speakers. This interlinking explains why Catalan politicians aim to keep up a sort of "Catalan unity", avoiding any kind of internal division in Catalan society. This division is a sort of sword of Damocles, invoked only to deny its existence. Both CiU (Convergència i Unió) and the PSC (Partit dels Socialistes de Catalunya) share this position, with small variances, which had previously been preached by the PSUC (Partit Socialista Unificicat de Catalunya, a Catalan Communist Party) during the time of its greatest influence.

\footnotetext{
3 Workshops have been organizad to support psychologically those Catalan speakers who want to abandon the tradicional norm of accommodation (switching) towards Spanish (Suay and Sanginés 2004)
} 
(c) Meanwhile, in the Balearic Islands and Valencia, the political party which has been longest in government (the conservative PP, People's Party) denies that there is any language "problem", simply because, outside of education, its policy is, as noted in other chapters of this book, to ensure that the nonCatalan-speaking population can avoid understanding or using Catalan.

To put it succinctly, the problem lies in establishing how "regional" governments (in the sense of them being subsidiary powers dependent upon a higher central government) of a linguistically-divided population can ensure the spreading of linguistic usage norms that favour Catalan without creating tensions amongst ethnic groups or with the central government. Campaigns on interpersonal usage also raise the issue of the limits of liberal democratic public powers, which cannot directly interfere in private usages (Branchadell 2005; see also his contribution to this volume). Intervention in private interpersonal usage is complex because:

(1) Legislation cannot be directly involved. It is true that Spain's supreme legislative text, its Constitution, makes understanding Castilian compulsory, as does the Statute of Autonomy of Catalonia for Catalan, but not those of the Balearic Islands or Valencia. Nevertheless, in all three territories, civil servants, given the language-related requirements for accessing their job, may be required (in theory, at least), to deal with the public (or students, in the case of Valencia) in the relevant language. Except in these cases, the choice is exclusively individual in nature ( $c f$. the controversy caused by a memo issued by a Minister of the Generalitat de Catalunya making the use of Catalan by civil servants compulsory (Rossich 1991)). It is significant that the Catalan government, unlike that of the Balearic Islands or some Valencian municipal councils, has not carried out any campaigns to promote the handing down of the Catalan language from generation to generation.

(2) Interpersonal usage does not take place in institutional organisations, making intervention more difficult.

(3) In the case of the Balearic Islands and Valencia, the difficulties in promoting the language -in all areas, not only in interpersonal usage- are greater due to questions of nomenclature, which some political forces are interested in keeping unresolved. In the Balearic Islands, although "Catalan" is the official name for the language, promotional campaigns tend to avoid using it, 
resorting to phrases such us "our language" or using names derived from those of the islands or even some of their towns or cities. In Valencia, the name used always, except in university circles, is "Valencian" (valencià), as included in the community's Statute of Autonomy.

Set out below is a breakdown by territory of the activities carried out, at an initial stage, to promote the interpersonal use of Catalan, which began in 1981 in Catalonia and ended in 1994 in Valencia (with a briefer period in the Balearic Islands), followed by a second stage, which began in Valencia in 1995 and has continued to the present day in all three Catalan-speaking territories.

\section{The beginnings of official language policy (1981-1995)}

The first campaigns in favour of the use of Catalan began in Catalonia and Valencia, where they were linked with the promulgation of the first language laws. Thus it was that, in Catalonia, the "la Norma" campaign (1981) preceded the Language Normalisation Act (1983) and, in Valencia, the equivalent legislation, the Valencian Usage and Teaching Act (1983) was followed by the "Parlem valenciă" ("Let's speak Valencian") campaign of 1984. In the Balearic Islands, the later implementation of the autonomous system delayed the commencement of the Islands' official language policy and, when this policy was finally implemented, the language act and the promotional campaigns were separated by a considerable amount of time. In fact, they were based on different political support. The law, which received the same name as that of Catalonia (the Language Normalisation Act), dates from 1986 and the first campaign from 19911992.

\subsection{The "la Norma" campaign (1981): "El català és cosa de tots"}

Catalonia's autonomous government organised its first language normalisation campaign between 1981 and 1982. Its goal was to extend the "bilingual norm" and make people aware of the need to progress towards so-called "sociolinguistic normality" in Catalonia. Aina Moll, the member of the Catalan government responsible for the matter, defined this "sociolinguistic normality" as the point in history when "all the inhabitants of Catalonia would understand and use Catalan, irrespective of their mother tongue" (Llibre Blanc...1982,17). Within this context, it was hoped that the practice of a "bilingual norm" would increase the public presence of Catalan and limit 
the need to use Castilian to the odd occasion when the interlocutor did not understand Catalan (La Campanya...1982, 11).

The "la Norma" campaign - using a play on words with the coincidence, in Catalan, between a girl's name (Norma) and the language's word for "the norm"- lasted from October 1981 to April 1982 (whilst the Catalan parliament worked on the first law promoting the Catalan language). Its main features are described below (Boix 1985):

(a) A non-confrontational campaign. The slogan "El català és cosa de tots" ("Catalan belongs to everyone") exemplifies the unifying tone that the campaign sought to convey. A commonly-distributed leaflet for the campaign stated: "Catalan belongs to everyone, to those who were born here and to those who come from elsewhere. Catalan is everyone's heritage because it is the living representation of the history and culture of Catalonia. Normalisation of Catalan forms a key part of the collective task that we all need to work on: the task of building a country for the future, which we all can consider ours and which is worth living in". The first step was to bring all of Catalonia's municipal councils on board. Councils representing $98 \%$ of the population put in writing their agreement with the "la Norma" campaign, undertaking to carry it out in their territories and, in some cases, organising their own subsidiary campaigns adapted in line with local needs. This first step had a twin objective. Firstly, it improved the effectiveness of the campaign. Secondly, it minimised any negative reaction, which proved minimal after this unanimous municipal support.

The second step was to implement the specifics of the campaign itself. A likeable, affable young lass of around ten was chosen as the personification of the campaign's message in a friendly, non-confrontational form. The goal, as stated in the campaign's white paper (Llibre Blanc) was to create "a movement sympathetic to the language, by means of gentle medium that would convey an irrefutable, integrative message (La Campanya...1983, 27)". Norma, the name of the girl, was ambivalent. Firstly, it could be either Catalan or Spanish. Secondly, it is the root of both the words "normalisation" and "normality". Norma was also meant to represent usage norms, both old and new, that the population should follow. 
Norma means in Catalan both the name of a young adolescent and the social norm. A lively, smart and gentle preadolescent epitomized the values of the campaign
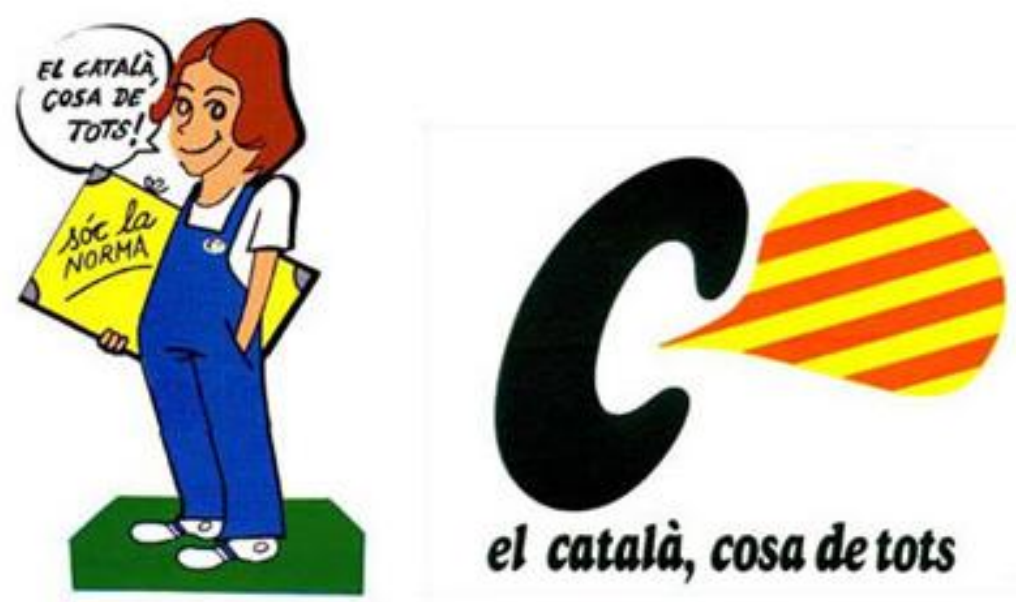

(b) The campaign's media: press cartoons and radio and TV ads. Promotional material, such as balloons, stickers, biros, lighters, etc., bearing Norma's image and her messages, were distributed throughout Catalonia. At various levels of involvement, schools and the mass media helped disseminate the campaign. For example, many television presenters wore or used Norma's gadgets, particularly during the last, most intensive months of the campaign. Also, hundred of speeches, debates and discussions on the subject took place in the majority of Catalonia's districts. The campaign reached its climax on 23 April, Sant Jordi (St. George's Day, the patron saint of Catalonia). From 9 March to 23 April, the core message was spread through cartoons in newspapers and magazines, small-scale video installations and short films in cinemas.

(c) The campaign's targets: ethnically-differentiated messages as well as neutral ones. The cartoons and short films appeared to be aimed at (1) Castilians, (2) Catalans, and (3) both groups, with a general, vague message.

(1) Messages aimed at Castilians. Cartoons 14, 16 and 19 encouraged Castilians to accept and demand the "bilingual norm" and were set in a range of situations (in a bar, on the street, at the doctor's) where they accepted and requested that they were spoken to in Catalan to be able to learn the language. 
The divergent language choice message is complicated: on the one hand it challenges the norm of accommodation with (or subordination to) Castilian; on the other, because it adds, in some cases exemplified in the cartoons, other norms (in commercial, doctor-patient, etc., relations) which also favour the choice of Castilian.

(2) Messages aimed at Catalans. More than half of the dialogues are unmistakeably aimed at Catalans: they follow the bilingual norm in the market, in the office and in groups of friends. The tone critical of traditional norms is tougher than in cartoons aimed at Castilian speakers. They therefore include Catalans (criticised, obviously) showing a lack of interest in the improvement in and genuineness of their language (cartoons 8, 9, 12 and 21) and those who fail to use it in formal or public contexts (cartoons 5, 10, 11, 15, 22 and 23)

(d) General messages aimed at both groups. Some cartoons do not appear to be aimed at any specific ethnic grouping. Some refer to Norma's personal traits, such as her obstinacy and sincerity. Others stress the need to speak any language correctly. This is the case of cartoon number 6, where Norma, who always speaks Catalan, corrects her Castilian-speaking interlocutors because they use unacceptable Catalan terms in their Castilian. Finally, some messages are consciously aimed at both groups. This is the case, for example of the dialogue A la visita mèdica (At the doctor's) which shows a process of double mutual convergence between the Catalan participant, (a), and the Castilian participant, (b). Firstly, the Catalan speaker adapts to (converges with) the Castilian interlocutor. Secondly, the Castilian speaker asks to be addressed in Catalan. The Catalan speaker ends up talking in Catalan, albeit a simplified version of the language, a "foreigner's talk", in which he clarifies some words that could be misunderstood. The linguistic divergence (choosing Catalan even though it is not the preferred code of the interlocutor) is compensated for by partial lexical convergence. This minimises any possible loss of face and the possible perception of rudeness.

The "la Norma" campaign managed to avoid any language-related arguments or disputes between Catalonia's two main ethno-linguistic communities, but this "success" came at the cost of an apparent failure to disseminate the "bilingual norm", which was 
its main objective. The tone of the entire campaign was extremely gentle and the incentives offered to adopt the new behaviour small. The campaign was condemned to ambiguity because it had to satisfy everyone. As the Head of the Language Policy Directorate remarked: "it is the first time that anyone has attempted to revive a language that has been oppressed for a long time and to give it its rightful place in the community, not only without excluding the oppressor language but even establishing a co-official nature with it. Many people -in and outside of Catalonia-doubted that such goals would be achievable" (La Campanya... 1983: 10).

The main incentive for following "la Norma's" advice was the need for national integration. Now "Catalan" would mean a common identity for both Catalans and Castilians, both ethnically and linguistically. In other words, the message was that, if one wanted to become truly Catalan, one had to learn Catalan. Above and beyond language planning considerations, there was an "identity planning" issue. Our impression is that such a general incentive is not enough. We believe that more utilitarian incentives, creating instrumental motivation, would have been more effective. One significant incentive of this type would have been as follows: companies and businesses requiring that those looking for jobs be sufficiently competent in the two languages, at least passively, to follow the "bilingual norm". If not, if there are no pressure-based measures of this type, it appears that the adaptation to Castilian norm will remain dominant in Catalonia. In 1997, arguments over the Language Policy Act show how difficult this point (the so-called "language availability") was. In the end, 1998 saw approval of a disposition stating that workers had to be able to deal with -in the sense of understanding but not necessarily answering-customers and the public in Catalan. This required a kind of "passive bilingualism", but not convergence towards the customer's language.

The Directorate-General of Language Policy, which did not carry out any form of serious assessment of the campaign, pointed out some limitations in its annual activities reports of 1982 and 1983. The emphasis was placed on the fact that it failed to reach many Castilian sectors of the population, and it was they who were the least aware of the sociolinguistic problems and challenges. Strubell, one of those heading the campaign, noted that "many Catalan speakers became more aware of their language. However, less impact was made on Castilian speakers than on other Catalans" (La Campanya...1983:73). The campaign did not manage to spread throughout the base and 
social networks of the Castilian-speaking world, although this was one of its specific goals. In some language normalisation exercises appearing in the newspaper El País (7 December 1986), a Castilian-speaking student was asked the following:

What would you suggest to Catalan speakers? And the response was: "In a linguistically-normal situation I, a Castilian speaker, would know that I have the right to learn and practise Catalonia's own language, and would not be scared of making my interlocutor impatient as I made an effort to express myself in it. I would not stop speaking in Catalan due to any fear of making errors: it would be very clear to me that it is better to speak a language badly than not to speak it at all. I would ask them to speak Catalan to me, so as to have the opportunity to practise it and learn it quickly.

One example of the campaign's lack of influence was the fact that, amongst the hundreds of cultural, social and sporting organisations and associations supporting the campaign, there were but a few trade union groups and only the odd neighbourhood association, in both cases, dominated by Castilian speakers.

\subsection{From "Parlem valencià" (1984) to "Visquem en valencià" (1990): an ambitious programme?}

Whilst Catalonia's first autonomous government worked on the basis that Catalan was used on a daily basis between Catalans and proposed that they went further and also used it with Castilians, in Valencia, symptomatically, the first Generalitat set a simpler goal: for the Valencians themselves to once again use their own language in everyday situations:

A casa, al carrer, al treball... parlem valencià (1984)

At home, on the street, at work... let's speak Valencian

It was with this message that the autonomous community's first government, made up by socialists (1982-1995), took up the old demand, expressed in clandestine graffiti, of the "Valencianist" movement. The campaign accompanied the then recently (and not unanimously) approved Valencian Use and Teaching Act (LUEV, 1983), whose goals were also fairly modest: to legalise the use of Catalan in teaching and other administrative fields. This basic campaign also covered other, lower-ranking ones, such as "Com et diuen" ("What's your name?", 1984), which aimed to inform Valencians of 
their right to officially change their surnames into their Catalan form; "Parlem en valencià" ("Let's speak in Valencian”, 1985), a variant of the general campaign aimed at young residents of tourist areas; "Bones Festes/Bon Nadal/Feliç Any Nou" ("Happy Holidays/Merry Christmas/Happy New Year", 1985), a campaign focusing on the retail trade and which included a "Letter to the Three Kings" and a large number of slogans designed to encourage people to learn and use the language: "On podem aprendre valencià" ("Where we can learn Valencian"), "El valencià té futur" ("Valencian has a future"), "Per aprendre un idioma cal practicar-lo" ("To learn a language, you have to practise it"). The generic campaign ("Parlem valencià") was spread through all types of mass media (television, radio, the press, telephone books and municipal newsletters) and advertising on the streets (billboards and telephone boxes). The subsidiary campaigns were disseminated to a lesser degree.

Note that the campaign focused its efforts on achieving a normal use of Catalan amongst Valencians by means of everyday-life language usage contexts, outside of strictly official or institutional areas and education. We do not know, however, the level of response to this campaign.

The autonomous body responsible for language planning in Valencia was named, in its first year of existence, the Servei de Normalització Lingüística (1982, Language Normalisation Service). However, the term normalisation, habitually used in similar bodies and laws in Catalonia and the Balearic Islands during these first years, immediately disappeared from the directory of the Valencian Generalitat, and, in line with the associated law (LUEV), was renamed the Valencian Use and Teaching Office (1983). It appears that the goals of a process of normalisation would necessarily have to be greater than those of a body and a section working in support of the use and teaching of a language named Valencian (maybe the strategic concealment of the name of the language behind the term "language normalisation" made people think more of "Catalan" than of "Valencian", and the supposition that it "hid" a wider idea of the language made the Valencian government change the name). Whatever the case, the increase in and greater complexity of the responsibilities being assumed by the Generalitat soon led to the body being divided into two: the Valencian Use Office and the Valencian Teaching Service (1987). In other words, for the first time, an official platform exclusively dedicated to promoting the language outside of its strict teaching was created. 
The assessment made of the language policy carried out by the Valencian Generalitat in the 1980s, according to the autonomous government itself, can be seen from the trends shown by some of the results of sociolinguistic surveys carried out at the end of the period (specifically, in 1989 and 1992). In these three years, the social usage of Catalan increased, both at home (+5.3 points) and in the retail trade (+4.1). In other words, these were not surveys targetting specific campaigns but rather measuring the indirect results that these may have had. In its comments on these results, the Valencian government repeatedly argued that it had to act above and beyond the demands of society on this point:

The majority of campaigns carried out, both the general as well as sectorial, have focused on boosting social usage. Usage has been promoted to a greater degree than that demanded by a large part of society, giving rise to greater positive appreciation of the use of Valencian and creating positive expectations.

(Conselleria de Cultura, Educació i Ciència 1995: 280)

The subsequent stage of the normalisation process carried out by the Generalitat was based around three themes: a new campaign, "Visquem en valenciă" ("Let's live in Valencian", 1990), a Three-Year Plan for the Promotion of the Use of Valencian in the Autonomous Community of Valencia (1990-1992) and the creation of the DirectorateGeneral of Language Policy (1991). However, the text explaining the new campaign slogan reduced its apparently more ambitious scope:

Visquem en valencià. Speaking. Knowing how to listen. Learning and teaching with enthusiasm. Participating and collaborating. Making Valencian a tool for living together in harmony. There is no better way of promoting the use of Valencian in our Autonomous Community. Let us in this way prepare for entry into a plurilingual Europe. (1990)

Note that, as highlighted by Branchadell (1996: 31), "living in Valencian" should involve the same goals as that set by official language planners in Catalonia: "that those citizens who so wish can live in Catalan in all spheres", something completely unthinkable in Valencia. The Valencian campaign had no such lofty goals but, quite the opposite, was notable for its significant degree of ambiguity, as seen in the above explanation. 


\section{en ValenCia}

"Let's speak Valencian". This banner was joined by the following text: "Speak. To know how to listen to. To learn and to teach with enthusiasm. Participate and collaborate. Make out of Valencian a tool of social harmony. There is no better way of boosting the use of Valencian in our community. Get ready to the entrance into the plurilingual Europe".

As with the previous campaign, this one was carried on television, radio, posters, billboards, press adverts, stickers, car sunshades, etc. -and even on a hot air balloon with the slogan that flew over various parts of Valencia. The campaign lasted three years (1990-1993). At the end of the second year, an assessment was performed in which the Generalitat stated that $86 \%$ of Valencians agreed with "encouraging the use of Valencian amongst all the inhabitants of the Autonomous Community of Valencia" (Conselleria de Cultura, Educació i Ciència 1995: 39-40). ${ }^{4}$

With the conversion at this stage of the Valencian Use Office into a Directorate-General of Language Policy, the body assumed greater importance in the Generalitat's administrative hierarchy, which indicated the associated greater importance given to the normalisation of the Catalan language by the new autonomous government.

Towards the end of the socialist period of government in the Generalitat (1993), it presented the General Plan for the Promotion of the Use of Valencian (PGPUV), which

\footnotetext{
4 The quoted source contains only one other piece of information on the level of acceptance (98\%) of campaign leaflets that were distributed by hand in 16,915 shops throughout the autonomous community.
} 
was relatively ambitious and, as a result, added to the existing slogan ("Visquem en valencià") the subsidiary slogan "Anem a més" ("Let's go further”). This announced progression, which was planned for implementation in the period until 1999, would be cut short by the socialists losing the autonomous community elections of 1995 . The text explaining the new campaign further highlighted the new subsidiary slogan, as an expression of the gradually increasing scope promised by the new plan with which it was associated:

Visquem en valencià. Anem a més. Generalitat Valenciana. La Comunitat. Let's live in Valencian. Let's go further. Valencian Government. The Community.

The PGPUV, which sprung from an analysis of the first ten years of normalisation and aimed to give the process a new boost, set "the goal of living in Valencian" (Conselleria de Cultura, Educació i Ciència 1995: 54-58) and did so beginning with the administration of the Generalitat itself and concluding with society as a whole: the establishment of measures for the effective use of the language (...) the increase in programmes that affect language-related attitudes and opinions, which increase the acceptability of these measures and foster a social situation favourable to the expansion of its use in Valencian society as a whole.

However, during these years of the first phase (1983-1995), although the Valencian Generalitat had the leading role, it was not the only player in the normalisation of Catalan in Valencia. Schools also worked in favour of the reintegration of Catalan in social usages, as did, especially, the Valencian School Federation which, in 1982, began organising large-scale district "encounters" between parents, teachers and students involved in the teaching of Catalan, which brought together an increasing number of people. These meetings were always held under a slogan, such as:

En valencià cap al futur

In Valencian, towards the future

Ara i sempre en valencià

Now and always, in Valencian

The most recent encounter (2007), supported by well-known Valencian actors who appear in two series on Canal 9, the Valencian public TV channel, took place under the slogan 
Matricula en futur. Matricula en valencià ${ }^{5}$

Enrol for the future. Enrol in Valencian.

Higher education also joined the efforts promoting the interpersonal usage of Catalan, since universities created their own language normalisation services. In principle, these services were designed to serve the university community but, indirectly, they also aimed to influence their social environment. The first campaign was carried out in the 1990-1991 academic year by the Language Policy Service of the University of Valencia. It was aimed at students in the last year of secondary school and the first year of university. Its goals were to inform them of the very existence of university's Language Service, on the language rights they enjoyed and of the teaching in Valencian carried out in the university. Its slogan was simple:

Trau la llengua (Bring the language out/stick your tongue out)

However, the majority of university campaigns have been organised on a common basis, with the gradual incorporation of other public universities (Jaume I -of Castelló de la Plana-, the Politècnica, Valencia, and Miguel Hernández, of Elx/Elche). The goal of the first campaign was to calm the environment hostile to the presence of Catalan on campus and to highlight the communicative aspect of the language:

Vull enrotllar-me amb tu. Em coneixes?

I want to get involved with you. Do you know me?

Tu i jo tenim una història. Escriu-me.

You and I have a story. Write to me.

Ens entenem. Parla'm.

We understand each other. Talk to me. (1991-1993)

\subsection{The first campaign in the Balearic Islands: "No et mosseguis la llengua" and "Treu la llengua" (1991-1992)}

By the end of the 1980s, and following the Language Normalisation Act in 1986, the lack of interest shown by the Islands' government in promoting the language led to the organisation Obra Cultural Balear arranging the signing of an agreement between the Islands' main political institutions (the government, Island Councils and Palma

\footnotetext{
${ }^{5}$ See http://www.fev.org/modules.php?name=News\&file=article\&sid=698
} 
Municipal Council) on the normalisation of the language (18/10/89; BOCAIB [The Official Journal of the Balearic Islands] 144, 21/11/89). This agreement created the Language Normalisation Campaign, a representative and administrative infrastructure, with financial support from the institutions, whose role was to plan and carry out language normalisation activities. It was headed by Aina Moll, who until recently had been Director-General of Language Policy in Catalonia. Right from the very beginning, the institutions did little or nothing to help the Campaign to be operative and it was, after a few years, dissolved due to inactivity. Amongst its most noteworthy actions were the advertising campaign "No et mosseguis la llengua. Parla català" ("Don't hold your tongue. Speak Catalan"), whose aim was for Catalan speakers to increase their interpersonal use of the language. It was based around TV and radio ads in which three well-known characters (one from each of the three islands) ${ }^{6}$ encouraged people to use Catalan. In parallel, billboards and press adverts supported the campaign. The campaign's modest level of funding and the lack of institutional involvement meant that it only lasted two months. Even so, this was the first time a powerful campaign in favour of Catalan had been carried out and, what is more, the first that the term Catalan had been used in such a carefree way, something that did not cause any significant negative reaction.

Simultaneously, the University of the Balearic Islands ${ }^{6}$, in collaboration with the Campaign, launched another campaign, aimed mainly at university students and schools ("Treu la llengua. Parla català", "Bring the language out / Stick out your tongue. Speak Catalan") ${ }^{7}$, which aimed to add a youthful perspective to the general campaign. This youth-oriented campaign, in addition to distributing calendars and t-shirts featuring the slogan, produced eight posters which, by means of a series of cartoons ( $\grave{a}$ la Norma), showed interpersonal usage situations requiring correction and which in some way represented the concerns in the field existing at the time: Catalan-speakers who spoke Castilian needlessly with their interlocutors, students who had learned Catalan but who did not use it in the outside world, the need to encourage those learning Catalan to use it, the break in the handing down of the language from generation to generation, etc.

\footnotetext{
6 This is another feature of language normalisation in the Balearic Islands: the need to reflect the existence of the different islands, due to the lack of a shared feeling of oneness between them.

7 The inspiration for this campaign came from the University of Valencia with its "Trau la llengua" campaign.
} 
At the same time, the University also carried out a campaign amongst students in favour of the normalisation of surnames.

\section{The changes in language policy in the second phase (from 1995)}

In all three Catalan-speaking regions, a second phase in the evolution of language policy can be discerned. Again in all three, this second phase is characterised by a change in government. In Catalonia, the successive governments of Convergència i Unió gave way to those of the "tripartite" (PSC-PSOE, ERC and Iniciativa per Catalunya), something which was seen as a new boost for Catalan language policy. This was also the case of the Balearic Islands, with the change from the PP to another three-party coalition (PSIB-PSOE, PSM and Esquerra Unida de les Illes Balears), which brought with it real qualitative change. In contrast, Valencia saw a change in the other direction, from the PSPV-PSOE to the PP.

\subsection{A second try in Catalonia: the "Tu ets mestre" and "Tu hi guanyes" campaigns (2003)}

For a long time, there were few new campaigns in Catalonia dealing with interpersonal usage. The only one worthy of note was "Depèn de vostè" ("It depends on you") of 1985 which, as its name suggests, placed the emphasis on the responsibility of Catalan speakers in language normalisation, on their duty not to change over systematically to Castilian. There were a number of negative reactions to this campaign, above all because is appeared that the authorities were avoiding their responsibilities ${ }^{8}$. Also worth mentioning is a campaign that was designed but never implemented: "En català ens entenem tots, fem-la (sic) servir" ("We all understand each other in Catalan, so let's use it”, 1993), which was based on the fact that the levels of understanding had increased greatly, so that the immense majority of the population understood Catalan (Consorci 1993). The campaign aimed to show, using three groups traditionally assumed to be Castilian-speaking (the police, taxi drivers and judges), how one could use Catalan and still be understood. The campaign was completed with the testimony of

\footnotetext{
8 Five years afterwards, a stinging attack on the situation of the language still mentioned it: "Obviously, the normalisation of Catalan depends, in the last instance, on the will of the Catalans themselves. However, in the first instance, it depends upon the conditions being created for Catalans to be loyal to their language" (...) "In a situation such as that facing us today, demanding that Catalans be faithful to their language, always and everywhere, more than a call for loyalty, is an invocation to heroism!" (Prats, Rafanell and Rossich 1990: 64-65).
} 
a former Barcelona player, Txiki Beguiristain, who had become fluent in Catalan, and this was the wish of the representatives of the groups selected to make statements in the associated adverts such as: "My name is Josep Martinez and I'm a taxi driver. I would like to ask you, on my behalf and that of many other colleagues of mine, when you use a taxi, not to hesitate to speak to us in Catalan". To conclude, a voiceover would state: "In the taxi and in Catalonia, we all understand each other in Catalan. Let's use it".

\subsubsection{The "Tu ets mestre" campaign (2003)}

The Generalitat de Catalunya began a communications campaign with the goal of promoting the linguistic integration of immigrants. It was aimed especially at Catalan speakers and its mission was to explain that, each year in Catalonia, more than 65,000 immigrants or foreigners learn Catalan and their efforts should be aided and made more useful by speaking to them in Catalan.

The campaign, carried out on television, radio, in the press and on outdoor media, was based on the fact that many Catalans did (and do) not usually address anyone who does not appear to be from Catalonia in Catalan, which might mean that those immigrants who are learning Catalan find that their efforts are of little use or feel excluded or discriminated against.

The television and radio ads showed three everyday-life situations: a market, a restaurant kitchen and a conversation between two skateboarder-style youngsters. In all three cases, a Catalan addresses in his or her own language an immigrant, who concluded the ad by saying "Ajuda'm, parla'm en catala" ("Help me. Speak to me in Catalan"). The press adverts showed a photo from each of the scenes under the slogan "Tu ets mestre" ("You are a teacher").

Of the more than 65,000 immigrants who learn Catalan each year, the majority almost 52,000- are children studying at schools (data for the 2002-2003 school year). The rest, i.e. around 15,000, are adults studying in centres of the Consorci per a la Normalització Lingüística (CPNL, Language Normalisation Consortium) or adult education centres, or at university.

Other immigrant-related measures are the financing of free basic Catalan courses offered by the CPNL, whatever the country of origin of the students, support for the language "welcome" programme for parents in the education system, and the voluntary 
language programme Hores de conversa (Hours of conversation), also offered by the CPNL. This Hores de conversa programme encouraged volunteers to spend an hour a week, for six to ten weeks each academic year, having conversation with beginner students to bolster their learning of spoken Catalan.

\subsubsection{The "En català, tu hi guanyes" campaign (June 2003)}

This campaign, similarly to the preceding one, aimed to promote the use of the Catalan language when dealing with the public. It consisted of posters of a chef, a lady shopping and a boy on the street.

Its goals were:

(1) To raise the awareness of Catalans in the retail and hotel/restaurant trade of the application of the 1998 Language Policy Act, the requirement that those involved with the public deal with customers speaking Catalan and their duty as business persons in the process of linguistic and cultural integration of foreigners

(2) To offer them support in the learning of Catalan by said staff, especially in the case of hiring foreigners, with teaching materials and training solutions.

(3) To convey to customers and users the message that they should speak in Catalan to those dealing with the public, even if they are foreigners, to help them to integrate.

(4) To ensure the assuming of responsibility and involvement of all the social players involved: Generalitat, Municipal Councils, employers' organisations, trades union, etc.

The direct target public were employers and workers in establishments open to the public, with the indirect targets being consumers and users.

The materials for employers consisted of explanatory leaflets. One bore the title "Obre les portes al català" ("Open the doors to Catalan"), whilst another, entitled "La llei del català de portes enfora i de portes endins" ("The Catalan Act outdoors and indoors"), noted the most important articles of the Language Policy Act, highlighting Article 32.1, which states that companies and establishments involved in the sale of products and rendering services which carry out their activity in Catalonia shall be in a position to be 
able to serve consumers when they express themselves in either of the official languages in Catalonia. The campaign consisted of a document entitled "El català t'obrirà moltes portes" ("Catalan will open up a lot of doors for you"), informing them in Catalan, Castilian and English of the advantages of learning Catalan, providing glossaries with an illustrated vocabulary and a list of terms and expressions ("Comencem a parlar" or "Let's begin to talk"), with an introduction in Castilian, French, English, Italian, German, Arabic and Chinese, a guide to good practices in customer services (a friendly greeting and positive language, for example), and a pocket guide to the most common expressions in a commercial relationship. A campaign leaflet explained what Catalan was, who spoke it and, most of all, why it was useful to learn it: "to become integrated in Catalonia, to progress in the world of work, to offer your customers good service and to relate to others better". It concludes with a text exhorting learners to: "Learn Catalan, dare to speak it, ask to be spoken to in Catalan. Your company, your colleagues and your unions will help you. In Catalan, you end up winning”. Clearly, the alleged help to be received from these sectors was a case of wishful thinking, since a large number of them are either Castilian speakers or Catalan speakers with little or no loyalty to the language.

\subsection{The last tries}

The reason for these campaigns are similar to that of previous ones: the failure to use Catalan in non-formal interpersonal situations, given the traditional norm of Catalan speakers changing into Castilian, also extended to amongst newly-arrived immigrants. The generalised levels of indifference and pragmatism have led to a clear reduction in the social usage of the language.

Its goal is to foster the interpersonal and informal use of the Catalan language.

\subsubsection{A third try: "La Queta: dóna corda al català" (2005)}

The slogan is "Dóna corda al català" ("Wind up Catalan") and is based around the idea that all the world's societies must "wind up" their languages, everyone must make use of them for them to remain living languages, and Catalan is no exception. These ideas are given concrete form in three main messages: 
All citizens are targeted by the campaign, but special emphasis is placed on the $25-45$ year-old age grouping "because it is they who are at an age to take decisions on how to bring up their children" (Pia Bosch, Diari de Girona, 25-I-2006)

(1) "Don't be scared to speak"

Because it doesn't matter if you make a mistake. What matters are your intentions. Because it is important that you speak, state your opinion and that you express yourself freely. Wind up Catalan. It's easier than it appears.

This message is aimed especially at those who understand Catalan but do not speak it. It invites them to speak a language they know, without worrying and with normality.

(2) "Speak freely"

Because it is up to you, and you alone, how you express yourself. Because it's your right. Because it's important that you speak freely whenever and wherever you want. Wind up Catalan and your word.

This message is aimed especially at Catalan speakers, encouraging them to use their language in any context.

(3) "To begin with, speak in Catalan!"

Because you have a lot to say. Because they'll understand you. Because it's important that you make it easy for others to speak in Catalan. Wind up Catalan so that it always progresses.

This is especially aimed at those who habitually speak Catalan, to make them aware that they are creating language behaviour models and to ensure they acquire the habit of starting conversations in Catalan when addressing unknown persons.

The campaign tried to make Catalan seem an anonymous language, belonging to everyone and not merely the authorities. It was explained thus in an assessment of the campaign (Informe...2005,1): "This is a popular campaign that must be acceptable to everyone, governed by political consensus and distanced from civic conflict. The campaign must be able to involve everyone, be popular and fun and, therefore, does not have the strict image of an institutional campaign. This campaign is a further product within a programme of measures for the dissemination of the Catalan language and, above all, its effective use". The same report highlights as positive the fact that "rather that "imposing" the speaking of Catalan or making those that do not do so feel guilty, the campaign encourages them to speak it and not be afraid of making mistakes, and to 
speak with complete freedom." The type of Catalan used is more that of a new speaker of the language that one for whom it has been their lifelong native tongue. It also notes as a more negative element that there is no clear branding, i.e. the fact that it is the government that is behind the campaign is not obvious. However, we believe that this lack of identification of the author of the campaign could, in fact, be positive, given the lack of regard in which the authorities are held. In this way, the anonymity of the Catalan is increased: it is everyone's and no-one's (Woolard 2005). Bernat Joan, the responsible of the Directorate of language policy, in an evaluation of the campaign (2008) emphasized the role of Catalan as lingua franca: "Catalan is everybody's language, not a property of a limited segment of Catalan society"(...) "Linguistic normalization precisely will mean that Catalan will be a meeting point between speakers of many different languages"

The autonomous government's assessment of the campaign was positive (Dóna corda 2004, 11). It had made la Queta, the campaign's mascot, and her songs, form part of the collective imaginary. A deeper goal was pointed out -the priority of Catalan as Catalonia's own (native) language: "This first stage (...) has been designed as a platform to encourage social reflection on the use of languages in Catalonia, on the basis of the preferential position that Catalan should have as the territory's own language" (p.11)9. Other more recent assessments can be found in Calaforra (2005).

\section{A smaller and slightly differerent campaign was boosted by the private organization} "Plataforma per la llengua altogether with the public network "Consorci per a la Normalització Lingüística”. Its motto was "Si us plau, parla’m en català" (Please, speak Catalan to me). The goal of the campaign was to try to convince Catalan speakers not to shift automatically to Spanish whenever they meet an immigrant interlocutor. In this case, immigrant citizens ( with Latin American traits, for example), are those who ask to be treated in Catalan.

\footnotetext{
9 This positive assessment also appears in a recent book (Pueyo 2007: 103) by the Secretary-General of Language Policy: Dóna corda al català, designed as a fresh image of a deliberately non-institutional, approachable, young and modern discourse, something which has been confirmed by a number of independent analyses, which received a magnificent reception from its target public and fiercely criticised by some leader writers who were shocked by such an informal representation of the Catalan language". Miquel Porta Perales (ABC, 28 January 2007) criticised the campaign as anti-liberal and identity-based: " (...) the jumping teeth that wish to inculcate in us the use of one language -and one only (...) que cada uno hable lo que quiera. Que cadascú parli el que vulgui" ("Let everyone speak what they want", in both Castilian and Catalan)
} 


\subsubsection{A fourth try.: "Encomana'm el català" ("Pass on Catalan”)}

Very recently, when correcting this volume, a new linguistic campaign has been carried out by the Catalan autonomous government. The main idea to be transmitted is that Catalan is easy and everybody can speak it. The enclosed picture shows how people from different races, origins and occupations, all are encouraged to speak Catalan. The core instructions say as follows: "In the bakery, at your friends's coffee.shop, with whom you already know and with whom you don't know, everywhere and with everybody, the first word in Catalan. It's easy. Pass on Catalan". The important presence of non European citizens in this picture is due to the rising numbers of non European workers in current Catalan society. ${ }^{10}$

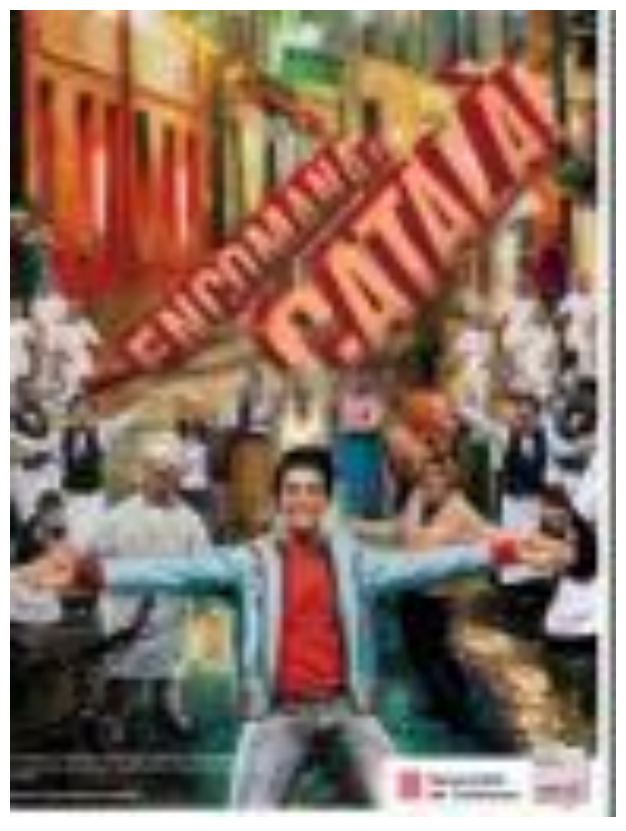

${ }^{10}$ In February 2009, a popular humour program in the main Catalan-speaking TV station, TV3, derided this campaign. The vicepresident of the Catalan government and leader of the independentist party, Carod-Rovira appeared to ask for a "tallat- ( coffee with milk) in Catalan when talking to a seemingly Latin American waiter. He repeated his request all night long by following faithfully the directions of the linguistic campaigns withouth obtaining any result: the waiter only replies with a gentle question in Spanish “¿Cómo dice?” (“What are you saying?”). Finally, already in the morning, Carod -Rovira, all bearded and exhausted, quits his linguistic struggle and switchs to Spanish. The reply of the waiter ( the punch line of the story) is , in Spanish: "Sorry, we don't have any milk" 


\subsection{Campaigns in Valencia, 1995-2007: the Generalitat versus the universities and the municipal councils}

The change in government of the autonomous community of Valencia from the PSPV-PSOE (Partit Socialista del País Valencià, Valencian Socialist Party) to the People's Party (PP, conservative) gave rise to a reverse in the timid progress made in the 12 years of left-supported governments. One of the most significant measures marked by the entry of the right into the Valencian Generalitat (1995) was the "demotion" and "dilution" of the organisational level that had been enjoyed by the Directorate-General of Language Policy, which was merged with the former Directorate-General of Education Management and Innovation. This meant that there was one Director-General in charge of a Directorate-General of Education Management and Innovation and Language Policy, in which the department for language planning played second fiddle to and was associated with education, which was where the PP intended to demote language policy, as occurred in the first socialist period when the first steps in the normalisation process took place. However, in addition to the aforementioned "relegation", the director of the affected area as a civil servant, which meant that there was no possibility of influencing the autonomous government's policy. During the most recent legislature (2003-2007), also controlled by the PP, it appeared that there was going to be a change in parallel to that of the replacement of those in charge of the area, but Language Policy remains the poorer relation of another Department, this time that of Culture (the Autonomous Secretariat of Culture and Language Policy), and its management remains in the hands of a Head of Area who is not a politician. Finally, and although this has barely been noticed, also significant has been the cut in the part of the Generalitat's budget set aside for language policy, from $0.1 \%$ in the times of the socialists to $0.044 \%$ in the years of right-wing government.

The scant language policy actually carried out by Valencian Generalitat has been restricted to lowering the tone of the socialists' campaign slogans to encourage the use of the language and to disseminate the new slogans as discretely as possible. The period began with "Valencià, clar que ŝ̋" ("Valencian, of course"), which obviously watered down the (at least apparent) intentions of the "Visquem en valenciă" of the second socialist period to the also barely committed slogan of later years "En valencià naturalment" ("In Valencian, naturally"). Each of the two campaigns carried out by the 
right in Valencia was accompanied by brief explanatory texts. Let us examine a few of these:

En valencià, clar que sí. Escrivim en valencià, parlem en valencià, estudiem en valencià... (1995-2005).

In Valencian, of course. We write in Valencian, speak in Valencian, study in Valencian, etc.

En valencià, naturalment. Perquè és la nostra llengua... Volem que parles, que contes coses. Anima't, trau-la ja! Per on vages, ja no t'ho penses. Anima't, parla ja! (2005-2007).

In Valencian, naturally. Because it is our language... We want to you talk, to explain things. Go on, bring it (stick it) out! Wherever you go, don't think twice. Go on, talk!

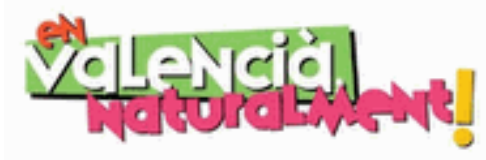

This last slogan has been spread by means of a song and a TV ad. All this has been rounded off with the publishing of folders and booklets complementing the lyrics of the song with verses such as these on the cover:

Perquè ja en som molts.

I és el teu moment.

Hui sentiràs el so d'una veu,

la veu del teu poble,

també de ta casa,

la veu que ha estat sempre.

És la teua veu.

Because there are already a lot of us.

And your time has come.

Today you will hear the sound of a voice,

That of your people,

And that of your home,

The voice that has always been there. 
That voice is yours.

Other subsidiary slogans, some derived from the explanatory text, have been presented in the form of television and radio adverts and include:

Relaciona't... viu en valencià

Get involved with people... live in Valencian

Trau la llengua ${ }^{11}$

Bring the language out/stick your tongue out

A l'hostaleria en valencià, naturalment

Hotels and restaurants in Valencian, naturally.

This latter subsidiary slogan has been promoted by means of leaflets and gifts of caps and posters alluding to it, only in the three districts with a clear Catalan-speaking majority and a positive attitude towards the language (la Ribera Alta, la Safor and la Vall d'Albaida), where they have enjoyed the support of their respective Language Services and the Valencian Hotel and Restaurant Federation.

Given the lack of language policy-related action by the Valencian Generalitat, the language services reporting to other authorities have decided to act on their own account and fill the gap left. Thus it is that local services (of the municipal and provincial authorities) on the one hand, and those of the universities on the other, have carried out coordinated action to make good the ineffectiveness of those of the autonomous community. Beginning in 1999, a network of local language staff has been created (albeit without any institutional support) with the goal of getting the most from efforts and financing in many initiatives which benefited not only their respective local areas but also managed to ensure dissemination throughout Valencia. To incentivise the use of Catalan by users of municipal offices, leaflets have been published stating the following:

En valencià a l'administració. Demana-ho en valencià, és el teu dret. Government in Valencian. Ask for it in Valencian. It's your right. And, more directly, mobile tabletop signs facing the public, stating:

\footnotetext{
11 Remember the success of this slogan, first used by the University of Valencia, then by the government of the Balearic Islands and, finally, by the Valencian Generalitat (see Note 7).
} 


\section{L'atenem en valencià}

We will deal with you in Valencian

To encourage new parents to create a Catalan-speaking environment on the occasion of the birth of their children, a range of different baby-related materials has been prepared ("baby on board" car signs, bibs, etc). The general slogan of the campaign was:

Benvinguts a casa (2003-2004)

Welcome home

The explanatory text accompanying it (in a smaller typeface and at much greater length) had every paragraph headed by short phrases (the first three of which are featured below) and was concluded with a longer one providing responses to the questions they had raised:

Ja sou pares. Enhorabona!

You're parents now. Congratulations!

$(\ldots)$

Quin nom li posem?

What name shall we give him/her?

$(\ldots)$

En quina llengua li parlem?

What language shall we speak to him/her in?

$(\ldots)$

Starting off in Valencian is to start off on the right foot. It's his/her life. It's our future.

On occasion, some municipal services have carried out campaigns on their own.

We set out some examples below, indicating which municipal council they belong to:

El valencià, cosa de tots ${ }^{12}$ (Alcoi)

Valencian belongs to everyone

12 This campaign was inspired by Catalonia's "El català, cosa de tots". 
Mirant el futur, a Elx parlem valencià (Elx/Elche)

Looking to the future, in Elx, let's speak Valencian.

Parlem valencià als fills (Novelda)

Let's speak Valencian to our children

El valencià val. Fem-lo valdre (Alzira)

Valencian is worth it. Let's make it worth it.

Sagunt a l'estiu, el valencià ben viu (Sagunt)

Sagunt in the summer, Valencian truly alive.

Declara't en valencià (Silla)

Declare yourself in Valencian

In 1995, by means of an agreement between the Valencian School Federation and twenty or so municipal language services, the Voluntariat pel Valencià (Volunteers for Valencian) programme was started. This involved bringing people who spoke Catalan into contact with those who did not so that, in pairs, they could talk in Catalan about everyday situations. The slogan and the brief explanation accompanying it are as follows:

\section{Vols que parlem?}

Vols ajudar a aprendre valencià?

Vols començar a parlar valencià?

Vols millorar el teu domini del valencià?

Vols aprendre valencià i passar-ho bé?

\section{Do you want us to talk?}

Do you want to learn Valencian?

Do you want to begin speaking Valencian?

Do you want to become more fluent in Valencian?

Do you want to learn Valencian and have fun?

Valencia's public universities have carried out campaigns linked to enrolment time and the presence of Catalan in teaching. Therefore, they are aimed at students to increase amongst them demand in their environment and, at the same time, influence the rest of society: 
Parla'm, marca'm en valencià (1994-1997)

Speak to me and mark me in Valencian

Tria'm en valencià (1997-1999)

Choose me in Valencian

Demana en valencià (1999-2002)

Ask for it in Valencian

Universitat en valencià (2002-2007)

University in Valencian

Matricula't en valencià (2006-2007)

Enrol in Valencian

The media used in support of the campaign have been posters about matriculation, billboards, diaries with the university calendar, aprons, individual tray cloths in dining rooms, folders and dividers, pencils and biros, bookmarks, wallets, bags, umbrellas, posters of other activities with the slogan, etc. In the case of the Universitat Jaume I, in Castelló, ever since 1998 they have held a fun run in freshers' week (with free t-shirt for participants) under the slogan:

Fem la carrera en valencià

Let's do our degree/race in Valencian

Alongside the enrolment campaigns, there are others that are wider in scope, either because they aim to reach other university sectors in addition to students, or because they go beyond the borders of Valencia's campuses and aim to influence society as a whole. The slogans set out below are addressed not only to teaching and research staff, but also at administrative and service personnel, to encourage them to use Catalan in their respective fields.

Jo treballe en valencià, $i$ tu? Nosaltres treballem en valencià, i tu? (2006)

I work in Valencian, and you? We work in Valencian, and you?

Ell ho deia en valencià, i tu? (2004-2007)

He said it in Valencian, and you?

Both slogans appear in a series of three bookmarks and three posters containing images of unknown people (in the case of the first slogan), and of three great Valencian writers 
(in the case of the second-Ausiàs March, Joan Fuster and V. Andrés Estellés), including in the latter case a quote from the author in question.

The wider-scope campaigns included the expansion into university campuses of the Voluntariat pel Valencià, from the 1996-97 academic year on, and the campaign to change names into their Catalan version:

I a tu com et diuen? (2006-2007)

And what do they call you?

However, the most daring (and recent) campaign regarding interpersonal use is this one by Valencia's public universities:

Cinema en valencià (2005-2007)

Films in Valencian

This involves providing a service that should have been supplied by Valencian Generalitat or by sector companies. As stated in the press release announcing the programme for 2007 :

This ambitious project to provide a programme of films in Valencian (...) to do something to remedy the absence of films in Valencian in Valencian cinemas -has become reality: now, the Valencian public arena, university-related and otherwise, looks forward to this traditional annual event featuring films in Valencian. It only remains to achieve the project's final goal: that Valencia's higher-level public institutions provide support for films in Valencian and that private initiative realises that there is a demand for films in Valencian, which is only timidly reflected in Valencian film listings, such that there is a normal supply of films in this language throughout the entire year.

\subsection{Campaigns in the Balearic Islands between 1999 and 2003}

Until a left-wing government won power in the Balearic Islands, after almost a decade of large-scale social mobilisation in favour of the Catalan language, led by Obra Cultural Balear, no campaign in favour of the normalisation of Catalan in interpersonal usage, or any other field, was again carried out. 
The first time that the government of the Balearic Islands assumed responsibility for a publicity campaign in favour of the normalisation of Catalan was in 2000. This campaign, "Donem la nostra llengua al futur" ("Let's give our language to the future"), consisted in the broadcasting of TV and press ads which aimed to favour the social legitimacy of the normalisation of Catalan in the Islands and attitudes favourable to the handing down of Catalan from generation to generation and language integration. One of the advertisements read:

For more than seven centuries, it has been our own voice, that has made us unique in the world. We have made Catalan progress from the middle ages to the twentyfirst century, generation after generation. What can stop us now? Today, as yesterday, for tomorrow: Let's give our language to the future.

Another ad in the same campaign stressed the need to use Catalan in all languagerelated functions to ensure its continuity as the Island's “own” (native) language. 2000 saw a revival of the campaign that had previously been carried out by the UIB to encourage people to register their names in Catalan (normalisation of names and family names).

With the same aim, that of socially broadening the perception that action in support of the normalisation of Catalan is legitimate, and taking advantage of the fact that 2001 was the European Year of Languages, together (also for the first time) with the Generalitat de Catalunya, it carried out the campaign "El català, llengua d'Europa" ("Catalan, a language of Europe"). This campaign consisted in the production of brochures and flyers, in a number of languages, which explained Catalan's place amongst the languages of Europe (its history, demographics, cultural production, lack of recognition as an official language within the EU, etc.). This was combined with press inserts containing this information (around 26 September, the European Day of Languages) and accessibility via the Internet. A video was also produced in the Islands, and broadcast by their TV stations under the same title, showing the history of Catalan from the perspective of the Balearic Islands and the situation in which it found itself. A DVD was later produced with access via a number of languages.

The same period also saw two campaigns (press advertisements and flyers) to encourage the reading of books in Catalan. The former ("Un regal, un llibre en català", "A gift, a book in Catalan", 2000), promoted the giving of books in Catalan as gifts. The second 
(“Agafa un llibre en català", "Take a book in Catalan”, 2001-2003) publicised the existence of books in Catalan on every imaginable subject and for all imaginable needs: practical books, entertaining ones, creative ones, translations, etc.

There is not doubt, however, that the most important publicity campaign of this period was "El català, una llengua per a tothom" ("Catalan, a language for everyone”, 20022003), designed to incentivise the linguistic integration of immigrants. It should be noted that the quantitative impact of immigration between 1999 and 2002 was clear: the proportion of the population born abroad doubled (from $7.4 \%$ to $15.4 \%)^{13}$.

Prior to the commencement of this campaign, a whole range of actions had already been carried out to the same end:

a) "Gent d'aqui" ("People from here", 2000-2001), a series of more than 40 TV programmes in which foreigners who had learned Catalan talked of their experiences and emphasised the importance of learning Catalan and how the locals had helped them to do so. This was broadcast by the Islands' TV channels, and summarised at the end of 2001 in a single programme under the same title, which was also produced in video form, together with a teaching guide to be used in secondary schools.

b) b) "Katalanischulen - Català fàcil" ("Easy Catalan", 2000-2002), mini radio programmes broadcast by the local German-language radio station (Inselradio), which invited the population of German origin to learn and use Catalan (which were later made into a $\mathrm{CD}$, "Parlem! 50 diàlegs per aprendre català. Lasst uns reden! 50 Dialogue um Katalanisch zu lernen" -“Speak to me! 50 dialogues to learn Catalan"- distributed amongst German residents) ${ }^{14}$.

c) "A l'abast" ("Within reach", 2000-2002), a multilingual CD-ROM with more than 250 basic Catalan phrases for non-Catalan speakers (and which is still available on the Internet) $)^{15}$.

d) "Cada dia una frase més" ("A new phrase every day”, 2001-2003), diaries, notebooks, inserts in the publications most popular with immigrants, and booklets

\footnotetext{
13 The Balearic Statistics Institute (IBAE): http://www.caib.es/ibae/demo/padro.htm (Consulta 02/05/07). 14 In 1999, 28.3\% of foreign residents in the Balearic Islands were German, the largest national grouping of all.

15 http://weib.caib.es/Recursos/abast/home.htm
} 
with 365 everyday phrases in Catalan and their translation into various languages (the version on the web allows you to hear spoken versions) ${ }^{16}$.

e) "Si tu vols, cap problema" ("If you want, no problem", 2000-2001), mini-radio programmes in the form of adverts, broadcast by all the stations of the SER chain on the Islands, which aimed, by broadcasting phrases in Catalan and Castilian, to incentivise the learning and use of Catalan, especially amongst Castilian speakers. Alongside these actions, which aimed to awaken in foreigners an interest in learning Catalan, specific teaching materials were drawn up, the quantity, quality and specificity of courses aimed at foreigners were increased, etc. (Ramon 2004).

2002 saw the beginning of the publicity campaign "El català, una llengua per a tothom" ("Catalan, a language for everyone", 2002-2003). The campaign used a wide variety of media: TV ads ${ }^{17}$ using real foreigners who had learned Catalan, radio ads, press advertisements, stickers, calendars (for 2003), etc. The campaign, subtitled "Oferiu-la. Demanau-la" ("Provide it, ask for it"), aimed to highlight the nature of Catalan as the Island's own, native language and to influence the behaviour of Catalan and nonCatalan speakers. Some of the materials were aimed at both groups together (roadside billboards, press ads, stickers, calendars, etc.) whilst in other cases they were aimed specifically at one or other group (radio and TV ads, flyers, etc.). The wording of the $\mathrm{TV}$ and radio advertisements speaks for itself with regard to their intentions:

There are people from around the world who want you to listen to and understand them, who are making efforts to integrate themselves in the Balearic Islands. Help them to learn our language. Catalan, a language for everyone.

The tri-fold flyers came in three versions: one explained the campaign's goals, whilst the other two explained the attitudes that should be held -one, in Catalan, was aimed at speakers of the language and the other, produced in a number of languages, at foreigners- explaining how they could both, from their different positions, contribute to the normalisation of the language.

In 2003, the campaign was bolstered by adverts aimed at the younger members of the population with a slogan which brought together the campaign carried out ten years previously by the University with that currently being promoted by the government:

\footnotetext{
16 http://web2.caib.es/frases/frases.jsp

17 This was broadcast by all the TV channels broadcast on the Islands, in addition to Catalonia's TV3.
} 
"Treu la llengua: el català una llengua per a tothom" ("Bring the language out/Stick your tongue out: Catalan is a language for everyone"). Different media were used: posters in telephone boxes, radio ads, film adverts in cinemas, etc.

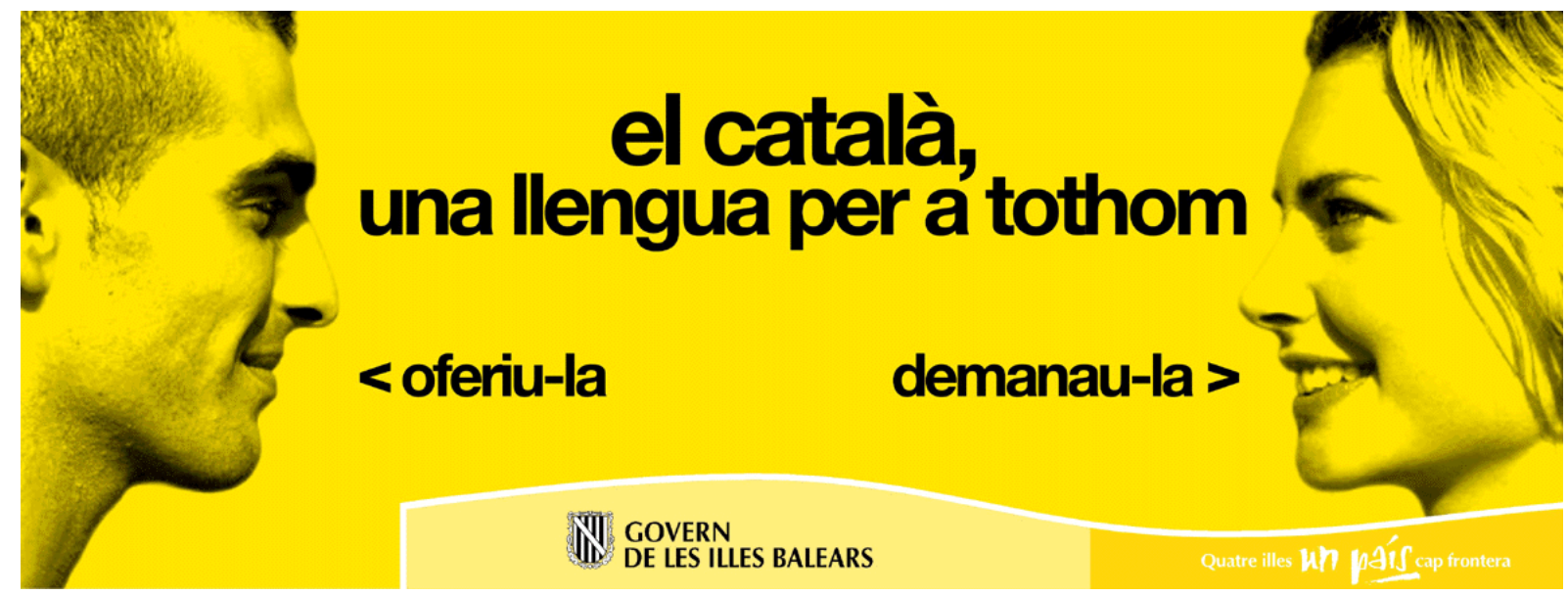

Catalan, a language for everybody. Let's offer it. Let's ask for it. Government of the Balearic Islands

In 2002, the Balearic Islands' government also carried out the campaign "Benvingut a ca teva" ("Welcome home"). This consisted in giving, via clinics and hospitals, families of newborn babies a folder (in a both boy and girl versions) with a range of materials encouraging them to keep on using the language with their children (in the case of Catalan speakers) or ensuring they had contact with it, to help them learn it, in other cases. The text accompanying the folder (girl version) ended by saying:

“[...] If you speak Catalan, don't hesitate to teach her our language, even if your partner speaks to her in a different one. If your family does not speak Catalan, make sure that your daughter learns the language of the Balearic Islands at school, in her pastimes, etc. Your personal decision today will be of great importance for the future of your child and of society. Start off on the right foot. It's her life. It's our future".

Similar campaigns were also carried out by Lleida's Language Normalisation Consortium and Valencian municipal councils (Minguet 2005). 
No systematic assessment has been carried out of any of these campaigns, but it can be confidently stated that they enjoyed great social acceptance, since there was a high level of involvement by social organisations (trades union, cultural and immigrants' associations, hospitals, etc.) and institutions voluntarily collaborating in the promotion and distribution of materials, etc. In 2003, the new government suspended all these campaigns and began no new ones, and this, together with the other measures it took, caused a reduction in the interest in learning Catalan, which can be seen in the progressive fall in matriculations in courses in the language for non-native speakers.

\subsubsection{Two campaigns by the Island Councils: "Tenim una llengua per sentir" (2004) and "Integra'm. Integra'l" (2005-2006)}

After the 2003 elections, the new conservative government of the Islands carried out no campaigns to encourage the use of Catalan. Nevertheless, the Council of Mallorca, governed by a regionalist party, and the Island Council of Minorca, governed by a leftwing/nationalist coalition, each carried out their own.

Mallorca's had as its slogan "Tenim una llengua per sentir" ("We have a language to be heard/felt"), which used a play on the word sentir, which in Catalan means both "to hear" and to "to feel emotionally". The campaign was based on the participation of 41 personalities (sportspersons, singers, professors, actors, business persons, journalists, etc.) either natives or non-natives, who announced, in press advertisements, their commitment to the use of Catalan -even though this name, when it did appear visually, was relegated to a less than prominent position. The use (or not) of the word depended on the preference of the individual participant: some used it without any problem, others referred to it by its "regional" name ("mallorquî") and other still employed a euphemism ("la nostra llengua" or "our language"). The accompanying general texts betrayed the balancing acts performed so as not to use the word "Catalan" when referring to the language:

A Mallorca tenim una llengua pròpia.

Molts dels que viuen aquí encara no la parlen, $i$ alguns ni tan sols l'entenen.

Si et sents mallorquí o vius a Mallorca, fes sentir la nostra llengua.

Tenim una llengua per sentir.

In Majorca we have our own language. 
Many of those who live here still do not speak it and some even do not understand it.

If you feel Majorcan or you live in Majorca, make our language heard/felt.

We have a language to be heard/felt.

The goal was to give Catalan social prestige and increase its use, as noted in the introductory web page ${ }^{18}$ :

We have to be able to attract all those around us so that they live their lives in our language in all social spheres. We must also be able to remain true to the undertaking we have assumed to involve ourselves in the language of Majorca.

The campaign used a variety of media, including the press, film adverts in cinemas, radio, television, etc.

At the end of 2005 and the beginning of 2006, the Island Council of Minorca provided support for the language pair programme "Integra'm (Xarxa de voluntaris per la llengua)" ("Integrate me, the language volunteer network") with the "Integra'm. Integra'l" ("Integrate me. Integrate them") campaign, shown in cinema and Minorca's television. In the adverts, a series of Minorcan celebrities appeared alongside immigrants and encouraged the population to adopt attitudes in favour of the integration of newcomers.

\section{Conclusions}

We have provided a description of the different campaigns in support of Catalan that intervene in interpersonal language usage, as implemented by the autonomous and local governments and the universities of three of Spain's autonomous communities: Catalonia, Valencia and the Balearic Islands. Each of these has been managed by political groups with different philosophies since the return of Spain to democracy in 1978.

One of the chief goals of these campaigns has been to counter the deep-rooted custom of only using the dominant Castilian language in public and inter-ethnic situations. The

18 http://www.conselldemallorca.net/llenguapersentir/inici.php 
campaigns also raise issues that could be of interest in other areas of the world attempting to revive a subordinated language.

On the one hand, they raise the issue of what are the limits of the authorities when intervening in individuals' private life. Some of the campaigns impact upon individuals as members of organisations, but others do so in completely private, family situations.

On the other, they raise the issue of the difficulty of assessing their impact. Given that any such assessments have been few and far between, when existing at all, it would appear that such campaigns can be reduced to a statement of intent, in a declaration of the "goodness" of the language that they wish to promote, without them having to have much real practical impact. It is, perhaps, significant that from the very first campaign, in 1981 , to the most recent ones in 2006, have all insisted on promoting the use of the language -a clear indication that their goal has not been achieved. Therefora an evaluation of the failure of these campaigns has been asked for (Branchadell 2009).

Could it be that the authorities are asking for more than the public is willing to do, as repeated claimed by the early Valencian Generalitat? Or, as in other areas, is it the case that the authorities are not doing as much as society might like?

\section{Bibliography}

Acadèmia Valenciana de la Llengua: Dictamen sobre els principis i criteris per a la defensa de la denominació i l'entitat del valencià, Acadèmia Valenciana de la Llengua, 2003 ("Documents" 04).

Blas-Arroyo, J. L. (2007). Spanish and Catalan in the Balearic Islands, International Journal of the Sociology of Language 184, pp. 79-93.

Bodoque, A. (2007). Les polítiques lingüístiques dels governs valencians, XII Jornada de Sociolingüística d'Alcoi (Alcoi, 24 de març de 2007).

Boix, E. (1985) 'The 'Norma' campaign in Catalonia: an attempt to influence interethnic language etiquette". Treball de curs no publicat. Linguistic Society of America Summer Institute.Georgetown University.

Branchadell, A. (1996). La normalitat improbable, Barcelona: Empúries.

Branchadell, A. (2005). La moralitat de la política lingüística. Un estudi comparat de la legitimitat liberaldemocràtica de les polítiques lingüístiques del Quebec i Catalunya, Barcelona: Institut d'Estudis Catalans.

Branchadell, A. "Fracassos lingüístics catalans” El Periódico 27/3/2009

Cabré, J. “Tu ets mestre”. Avui 1/2/2003. 
Calaforra, G. (2005) “Avaluació de la presència de la campanya 'Dóna corda al català' a la premsa”. Informe per a la Secretaria de Política Lingüística de la Generalitat de Catalunya.

Calsamiglia, H. \& Tuson, A. (1984). Ús i alternança de llengües en grups de joves de Barcelona: Sant Andreu del Palomar. Treballs de sociolingüística catalana, 3, València, Tres i Quatre, pp. 11-82.

Conselleria de Cultura, Educació i Ciència (1995). Balanç i perspectives de la promoció del valencià. 1994-1995, Generalitat Valenciana, València.

Consorci per a la Normalització Lingüística (1993). Projecte de campanya publicitària per a dinamitzar l'ús social del català. Direcció d'imatge, relacions i coordinació.

Cooper, R.L. (1982). A framework for the study of language spread. In Cooper, R.L. (ed.) Language Spread. Studies in Diffusion and Social Change. Washington DC: CAL, 5-36.

Departament de Cultura de la Generalitat de Catalunya (1983). La Campanya per a la normalització 1983. Barcelona: Generalitat de Catalunya.

Direcció General de Política Lingüística (1983). Llibre blanc de la Direcció General de Política Lingüística. Barcelona: Generalitat de Catalunya.

Esteve, A. \& Esteve, F. (2007). Drets cap a la normalitat. Propostes per a una política lingüística eficaç i factible al País Valencià, València: Tres i Quatre.

Genesee, F. (1982). The Social Psychological Significance of Code Switching in CrossCultural Communication, Journal of Language and Social Psychology, 1 1982; vol. 1: pp. 1 - 27.

Giles, H. \& Johnson, P. (1981). The role of speech in ethnic group behavior. Dins J.C. Turner i H. Giles (eds.) Intergroup behavior. Chicago: Chicago University Press, 199-243.

Gimeno-Menéndez, F. i Gómez-Molina, J.R. (2007). Spanish and Catalan in the Community of Valencia. International Journal of the Sociology of Language 184, 95-107.

Informe final post test de la campanya "Dóna corda al català". Barcelona: Synovate add impact.

Joan,B.(2008) “Algunes consideracions sobre la campanya per a l'ús social de la llengua catalana". Llengua i ús 43, 2-4.

La campanya per la normalització lingüística de Catalunya, 1982 (1983). Barcelona: Generalitat de Catalunya, Departament de Cultura.

Minguet, E. (2005). Els processos de normalització lingüística en l'àmbit municipal valencià, Servei de Publicacions. València: Universitat de València.

Moll, A. (1985). Entrevista amb Aina Moll: "Baixar la guàrdia pot fer perillar la normalització". El Món, 19 d'abril 1985.

Montoya, B. (2006). Normalització i estandardització, Institut Interuniversitari de Filologia Valenciana / Alzira: Bromera ("Biblioteca Essencial", núm. 7).

Prats, M., Rafanell, A. \& Rossich, A. (1990). El futur de la llengua catalana, Barcelona: Empúries. 
Pueyo, M. (2007). El fantasma de la mort del català. Cap a un nou discurs sobre la llengua catalana. Barcelona: Proa.

Ramon, N. (2004). Immigració i acolliment lingüístic a les Illes Balears, Treballs de sociolingüística catalana 18, 161-175.

Rossich, A. (1991). El fons de la qüestió. El País (7-II-1991)

Serrano, A. R. \& Victoriano, J.E. (2002). La normalització lingüística i l'administració local a les comarques alacantines (1980-2002), El valencià a Alacant. Canelobre, $47,62-73$.

Simó, M. et al. (2006) “Aproximació a l'avaluació de la campanya 'Dóna corda al català"” (I) Llengua i ús 35, 26-32.

Simó, M. et al. (2006) “Aproximació a l'avaluació de la campanya 'Dóna corda al català’”(II) Llengua i ús 36, 26-35.

Simó, M. et al. (2007) 'Principals resultats de l'avaluació de la campanya 'El català va amb tu"”. Llengua i ús 38,62-68.

Street, R. L. and Giles, H. (1982). Speech accommodation theory: A social cognitive approach to language and speech behavior. In M. Roloff and C. R. Berger (eds.), Social cognition and communication (pp. 193-226). Beverly Hills, CA: Sage.

Strubell, M. (1984). Language and identity in Catalonia. International Journal of the Sociology of Language 47, 91-104.

Strubell, M. (1992). Les campanyes de normalització lingüística de la Generalitat de Catalunya 1980-1990. Revista de Llengua i Dret 18, 181-192.

Suay, F. and Sanginés, G. (2004) "Un model d'anàlisi i intervención en la submissió lingüística”. Anuari de Psicologia 9 (1), 97-111.

Secretaria de Política Lingüística (2005). Dóna corda al català, Llengua i Ús 33, 4-11.

Use Catalan, everybody comes out winning. (2005). Departament de Comerç. Generalitat de Catalunya.

Vallverdú, F. (1972). Ensayos sobre el bilingüismo. Barcelona: Península.

Vallverdú, F. (1979). Algunes consideracions sobre política lingüística. In Vallverdú, F. La normalització lingüística a Catalunya. Barcelona: Laia, 43-62.

Vallverdú, F. (1989). “El bilingüisme passiu en qüestió?” Avui (16-II-1989)

Vila-Pujol, M. R. (2007). Sociolinguistics of Spanish in Catalonia. International Journal of the Sociology of Language 184, 59-77.

Woolard, K.A. (1983). The Politics of Language and Ethnicity in Barcelona. Ph. D. Dissertation. University of California, Berkeley.

Woolard, K.A. (1985). Catalonia: the Dilemma of Language Rights. In N. Wolfson \& J. Manes (eds.) Language and Inequality. Berlin: Mouton, 91-109.

Woolard, K.A. (2005). Les ideologies lingüístiques: una visió general des de l'antropologia lingüística (versió 8/18/05). 
